\title{
The effect of Cratylia floribunda lectin on renal hemodynamics and ion transport
}

\author{
Alexandre Havt ${ }^{1}$, Ana Maria Sampaio Assreuy ${ }^{2}$, Nilberto Robson Falcão do Nascimento ${ }^{2}$, Manassés \\ Claudino Fonteles ${ }^{2}$, Lívia de Paula Pereira ${ }^{2}$, Sandra Maria Nunes Monteiro ${ }^{1}$, Paulo Sergio Ferreira \\ Barbosa $^{1}$, Kyria Santiago do Nascimento ${ }^{3}$, Benildo Sousa Cavada ${ }^{4}$, Alice Maria Costa Martins ${ }^{4}$, \\ Helena Serra Azul Monteiro ${ }^{1}$
}

\author{
${ }^{1}$ Departamento de Fisiologia e Farmacologia, Universidade Federal do Ceará, UFC, Fortaleza, Ceará, Brasil, \\ ${ }_{2}^{2}$ Instituto Superior de Ciências Biomédicas, Universidade Estadual do Ceará, UECE, Fortaleza, CE, Brazil, ${ }^{3}$ BioMol- \\ Lab, Departamento de Bioquímica e Biologia Molecular, Universidade Federal do Ceará, UFC, Fortaleza, CE, Brazil, \\ ${ }^{4}$ Departamento de Análises Clínicas e Toxicológicas, Faculdade de Farmácia, Odontologia e Enfermagem, Universidade \\ Federal do Ceará, Fortaleza, CE, Brazil
}

\begin{abstract}
Lectins have been described as glycoproteins that reversibly and specifically bind to carbohydrates. Legume lectins isolated from the subtribe Diocleinae (Canavalia, Dioclea and Cratylia) are structurally homologous with respect to their primary structures. The Diocleinae lectins of Canavalia brasiliensis, Dioclea guianensis and Canavalia ensiformis have been shown to distinctly alter physiological parameters in isolated rat kidneys. Thus, the aim of this study was to investigate the effect of Cratylia floribunda lectin (CFL) on renal hemodynamics and ion transport in rats. In isolated perfused kidneys, CFL (10 $\mu \mathrm{g} / \mathrm{mL}, \mathrm{n}=5$ ) increased $\mathrm{RPP}, \mathrm{RVR}$ and decreased $\% \mathrm{TK}+$, but did not change urinary flow, glomerular filtration rate, sodium or chloride tubular transport. In isolated perfused mesenteric bed, CFL ( 3 and 10 $\mu \mathrm{g} / \mathrm{mL} / \mathrm{min} ; \mathrm{n}=4)$ did not alter tissue basal tonus or tissue contraction by phenylephrine $(1 \mu \mathrm{M} / \mathrm{mL} / \mathrm{min})$. In conclusion, the seed lectin of Cratylia floribunda increased renal hemodynamic parameters showing a kaliuretic effect. This effect could be of tubular origin, rather than a result from haemodynamic alterations.
\end{abstract}

Uniterms: Plant lectin. Amiloride. Cratylia floribunda/lectina/renal hemodynamics. Renal hemodynamics. Ion-transport.

As lectinas são descritas como (glico)proteínas que se ligam, especificamente e reversivelmente, a carboidratos. Lectinas de leguminosas isoladas da subtribo Diocleinae (Canavalia, Dioclea e Cratylia) são estruturalmente homólogas em relação às suas estruturas primárias. Demonstrou-se que as lectinas de Diocleinae Canavalia brasiliensis, Dioclea guianensis e Canavalia ensiformis alteram diferentemente parâmetros fisiológicos em rins isolados de ratos. Dessa maneira, o objetivo deste estudo foi investigar o papel da lectina de Cratylia floribunda (CFL) na hemodinâmica renal e no transporte de íons em ratos. Em rins isolados perfundidos, CFL $(10 \mu \mathrm{g} / \mathrm{mL}, \mathrm{n}=5)$ aumentou a pressão de perfusão renal, a resistência vascular renal e reduziu o percentual do transporte tubular de $\mathrm{K}^{+}$, mas não alterou o fluxo urinário, a taxa de filtração glomerular e o percentual de transporte tubular dos íons sódio e cloreto. No leito mesentérico isolado perfundido, CFL (3 e $10 \mu \mathrm{g} / \mathrm{mL} / \mathrm{min}, \mathrm{n}=4)$ não alterou o tônus basal ou a contração do tecido induzida por fenilefrina $(1 \mu \mathrm{M} / \mathrm{mL} / \mathrm{min})$. Em conclusão, a lectina de sementes de Cratylia floribunda altera parâmetros hemodinâmicos renais, provavelmente de origem tubular, e não por alterações hemodinâmicas.

Unitemos: Lectina vegetal. Amilorida. Cratylia floribunda/lectina/hemodinâmica renal. Hemodinâmica renal. Transporte de íons.

\footnotetext{
*Correspondence: A. M. C. Martins. Departamento de Análises Clínicas e Toxicológicas. Faculdade de Farmácia, Odontologia e Enfermagem. Universidade Federal do Ceará. Rua Capitão Francisco Pedro, 1210 - 60430-370 - Fortaleza - CE, Brasil. E-mail: martinsalice@gmail.com
} 


\section{INTRODUCTION}

Lectins have been described as carbohydratebinding proteins widely distributed in animals, plants and microorganisms (Yamazaki et al., 2000). Plant lectins isolated from seeds of the Diocleinae subtribe present high structural homology $(80-90 \%)$ and are the most investigated, especially those of the genera Canavalia, Dioclea and Cratylia (Ingham, 1990). The lectin studied here is a metalloprotein, isolated by affinity chromatography from seeds of Cratylia floribunda (CFL) (family Leguminosae, Tribe Phaseoleae, Subtribe Diocleinae), that requires divalent ions $\left(\mathrm{Ca}^{2+} / \mathrm{Mn}^{2+}\right)$ for full biological activity (Oliveira, Cavada, Moreira, 1991). CFL presents glucose/mannose binding specificity for conserved binding sites of asparagine-linked oligosaccharides or deoxy analogs (Dam et al., 1998). In addition, CFL has a multimeric structure composed of identical monomers of $25.5 \mathrm{KDa}$ and exhibits distinct pH-dependent dimer-tetramer equilibrium (Calvete et al., 1999; Del Sol, Cavada, Calvete, 2007).

Despite the structural similarities, Diocleinae lectins exhibit distinct biological activities, varying in potency and efficacy in comparison with CFL: lower mitogenic activity of Canavalia ensiformis lectin (ConA) in human blood mononuclear cells (Barral-Netto et al., 1992); higher histamine secretory activity of many Diocleinae lectins in rat peritoneal mast cells (Gomes et al., 1994). In addition, the higher affinity of CFL for glucose-mannose binding sites on the eye and mouth mucosal surfaces in relation with other glucose-mannose lectins (Banchonglikitkul et al., 2000) and its intermediate inhibitory activity in relation to the lectins of Dioclea violacea and Dioclea guianensis (DguiL) on the rat peritonitis and paw edema (Assreuy et al., 1997).

In respect to renal effects of Diocleinae lectins, our group demonstrated that the lectin of Canavalia brasiliensis (ConBr) (Teixeira et al., 2001), DguiL and ConA (Havt et al., 2003) distinctly alter physiological parameters in ex vivo rat kidneys. Considering that kidneys are responsible for the maintenance and excretion of electrolytes in the human body and the structure-activity relationship among Diocleinae lectins, the direct renal effects promoted by the seed lectin of Cratylia floribunda in isolated perfused kidneys and mesenteric bed of rats were investigated.

\section{MATERIAL AND METHODS}

\section{Wistar rats}

Animals, maintained with free access to water and fasted for $24 \mathrm{~h}$ before experiments, were anesthetized with sodium pentobarbital $(50 \mathrm{mg} / \mathrm{kg}$ body weight; i.p.). Experimental protocols were approved by the Animal Care and Use Committee of the Federal University of Ceara (UFC $\left.{ }^{\circ} 107 / 07\right)$, according to international guidelines (NIH publication n $\left.{ }^{\circ} 85-23,1985\right)$. ' Guide to the Care and Use of Experimental Animal Care" (Canadian Council on Animal Care guidelines, 1984).

\section{Rat kidney perfusion}

The right kidney $(\mathrm{n}=5)$ of rats $(260-320 \mathrm{~g})$ was carefully dissected and the renal artery was cannulated via mesenteric artery (Bowman, 1970; Fonteles et al., 1983) and perfused with modified Krebs-Henseleit solution (MKHS; mmol/L): $114.00 \mathrm{NaCl}, 4.96 \mathrm{KCl}, 1.24 \mathrm{KH}_{2} \mathrm{PO}_{4}$, $0.5 \mathrm{MgSO}_{4} 7 \mathrm{H}_{2} \mathrm{O}, 2.10 \mathrm{CaCl}_{2}$ and $24.99 \mathrm{NaHCO}_{3}$. Bovine serum albumin-fraction V (BSA; $6 \mathrm{~g})$, urea $(0.075 \mathrm{~g})$, inulin $(0.075 \mathrm{~g})$ and glucose $(0.15 \mathrm{~g})$ were added to 100 $\mathrm{mL}$ of MKHS and the $\mathrm{pH}$ was adjusted to 7.4. In the experiments, $100 \mathrm{~mL}$ of MKHS were perfused for 120 min as control.

Renal perfusion pressure (RPP) was measured at the tip of the stainless steel cannula in the renal artery. Renal vascular resistance (RVR) was calculated by dividing the RPP by the flow, measured in a flowmeter. Urinary flow (UF) was measured directly and glomerular filtration rate (GFR) by the clearance of inulin (Walser, Davidson, Orloff, 1955, Fonteles et al. 1983). Osmolality was evaluated by means of a vapor pressure osmometer (Wescor 5100C, USA). Samples of urine and perfusate were collected at $10 \mathrm{~min}$ intervals. Electrolytes $\left(\mathrm{Na}^{+}, \mathrm{K}^{+}\right.$and $\left.\mathrm{Cl}^{-}\right)$were measured using ion-selective electrodes (Rapid Chem $744^{\circledR}$, Bayer Diagnostic, $\mathrm{UK})$ and sodium $\left(\% \mathrm{TNa}^{+}\right)$, potassium $\left(\% \mathrm{TK}^{+}\right)$ and chloride $(\% \mathrm{TCl})$ tubular transport were calculated (Martinez-Maldonado, Opava-Stitzer, 1978). CFL (10 $\mu \mathrm{g} /$ $\mathrm{mL}$ ) was added to the organ bath $30 \mathrm{~min}$ after the perfusion was initiated. In another set of experiments, amiloride $\left(10^{-4}\right.$ M), a distal tubular sodium channel blocker, was added at 0 time (immediately after a 20 -min equilibration period), 30 min before the CFL challenge. All experiments lasted $120 \mathrm{~min}$ and results were compared to the internal control groups (inside the group) or to time-matched controls (between groups).

\section{Mesenteric bed perfusion}

The abdomen of rats (280-350 g) was opened for tightening of pancreatic-duodenal, ileum-colic and colic branches of the superior mesenteric artery. The superior mesenteric artery was cleaned of surrounding tissue 
and cannulated with a polyethylene tube (PE20). The mesenteric bed $(n=4)$ was perfused with MKHS with addition of $3.60 \mathrm{mM}$ glucose at $37^{\circ} \mathrm{C}$ at a flow rate of 4 $\mathrm{mL} / \mathrm{min}$ (MCGREGOR 1965). Direct vascular effects of CFL ( 3 and $10 \mu \mathrm{g} / \mathrm{mL} / \mathrm{min}$ ) or phenylephrine $(1 \mu \mathrm{M} /$ $\mathrm{mL} / \mathrm{min}$ ) after $10 \mathrm{~min}$ of infusion were compared to the vehicle. Endothelium integrity was evaluated by addition of acetylcholine $(1 \mu \mathrm{M})$ in the plateau-phase of phenylephrine-induced contraction. Perfusion pressure was measured using a pressure transducer (Statham P23, Gould, Oxnard, CA, USA) and recorded on a four-channel physiograph (Narco BioSystems, Houston, TX, USA).

\section{Statistical analysis}

Results were presented as mean \pm S.E.M. and compared by the Student test. Statistical differences were adopted for $\mathrm{p}$ values $<0.05$.

\section{RESULTS AND DISCUSSION}

CFLincreased RPP and RVR at $90 \min \left(\%_{\mathrm{RPP}}=11.2\right.$;
$\left.\%_{\mathrm{RVR}}=8.7\right)$ and $120 \mathrm{~min}\left(\%_{\mathrm{RPP}}=13.9 ; \%_{\mathrm{RVR}}=18.6\right)$, whereas GFR and UF were unchanged (Table I). Amiloride decreased RPP and RVR at $60 \mathrm{~min}\left(\%_{\mathrm{RPP}}=15.1\right.$; $\left.\%_{\mathrm{RVR}}=16.0\right), 90 \mathrm{~min}\left(\%_{\mathrm{RPP}}=21.4 ; \%_{\mathrm{RVR}}=25.3\right)$ and $120 \mathrm{~min}\left(\%_{\mathrm{RPP}}=25.1 ; \%_{\mathrm{RVR}}=24.2\right)$. However, the addition of amiloride before CFL potentiated the CFL increased effect on RPP and RVR at $90 \min \left(\%_{\mathrm{RPP}}=12.5 ; \%_{\mathrm{RVR}}=8.9\right)$ and $120 \mathrm{~min}\left(\%_{\mathrm{RPP}}=34.6 ; \%_{\mathrm{RVR}}=39.2\right)$. Moreover, CFL plus amiloride increased GFR and UF at $60 \mathrm{~min}\left(\%_{\mathrm{GFR}}=90.6\right.$; $\left.\%_{\mathrm{UF}}=52.6\right), 90 \mathrm{~min}\left(\%_{\mathrm{GFR}}=175 ; \%_{\mathrm{UF}}=78.9\right)$ and $120 \mathrm{~min}$ $\left(\%_{\mathrm{GFR}}=178 ; \%_{\mathrm{UF}}=126.3\right)$ (Table I). In the mesenteric bed, CFL did not alter either the tissue basal tonus nor decreased the high tonus induced by phenylephrine (Figure 1).

These results are suggestive of an indirect effect of CFL on renal hemodynamics. It is known that the increase in renal vascular resistance can lead to the increase in glomerular filtration and urinary flow. However, the present results showed that these effects could follow independent mechanisms (Koeppen, Stanton, 1997). Previous studies had demonstrated important vasodilator effects of lectins belonging to the genus Canavalia, that

TABLE I - Renal effects of the lectin from Cratylia floribunda seeds

\begin{tabular}{|c|c|c|c|c|}
\hline Renal parameters & $30 \mathrm{~min}$ & $60 \mathrm{~min}$ & $90 \mathrm{~min}$ & $120 \mathrm{~min}$ \\
\hline \multicolumn{5}{|l|}{ RPP ( mmHg) } \\
\hline Control & $110.11 \pm 3.68$ & $108.27 \pm 4.88$ & $108.69 \pm 5.09$ & $110.28 \pm 3.69$ \\
\hline Amiloride & $111.10 \pm 1.30$ & $91.90 \pm 5.70^{*}$ & $85.40 \pm 2.30 *$ & $82.60 \pm 1.50 *$ \\
\hline CFL & $107.70 \pm 2.30$ & $116.80 \pm 2.40$ & $120.90 \pm 4.00 *$ & $125.60 \pm 4.20 *$ \\
\hline $\mathrm{CFL}+$ Amiloride & $107.80 \pm 1.70$ & $106.90 \pm 3.90$ & $122.30 \pm 5.20^{*}$ & $148.40 \pm 5.20 *$ \\
\hline \multicolumn{5}{|c|}{$\operatorname{RVR}\left(\mathrm{mmHg} / \mathrm{mL} \cdot \mathrm{g}^{-1} \cdot \mathrm{min}^{-1}\right)$} \\
\hline Control & $5.39 \pm 0.10$ & $5.57 \pm 0.02$ & $5.76 \pm 0.05$ & $5.49 \pm 0.08$ \\
\hline Amiloride & $5.60 \pm 0.20$ & $4.68 \pm 0.37 *$ & $4.30 \pm 0.18^{*}$ & $4.16 \pm 0.14^{*}$ \\
\hline CFL & $5.58 \pm 0.23$ & $6.00 \pm 0.16$ & $6.26 \pm 0.30^{*}$ & $6.51 \pm 0.32^{*}$ \\
\hline $\mathrm{CFL}+$ Amiloride & $5.54 \pm 0.17$ & $5.48 \pm 0.23$ & $6.27 \pm 0.27^{*}$ & $7.64 \pm 0.34^{*}$ \\
\hline \multicolumn{5}{|l|}{ GFR (mL.g $\left.{ }^{-1} \cdot \mathrm{min}^{-1}\right)$} \\
\hline Control & $0.77 \pm 0.05$ & $0.74 \pm 0.02$ & $0.70 \pm 0.03$ & $0.73 \pm 0.03$ \\
\hline Amiloride & $0.74 \pm 0.08$ & $0.67 \pm 0.11$ & $0.58 \pm 0.09$ & $0.60 \pm 0.07$ \\
\hline CFL & $0.76 \pm 0.04$ & $0.85 \pm 0.07$ & $0.87 \pm 0.14$ & $0.81 \pm 0.11$ \\
\hline $\mathrm{CFL}+$ Amiloride & $0.90 \pm 0.09$ & $1.41 \pm 0.21^{*}$ & $1.93 \pm 0.32 *$ & $2.03 \pm 0.29^{*}$ \\
\hline \multicolumn{5}{|l|}{ UF (mL.g $\left.{ }^{-1} \cdot \mathbf{m i n}^{-1}\right)$} \\
\hline Control & $0.17 \pm 0.01$ & $0.19 \pm 0.01$ & $0.19 \pm 0.01$ & $0.19 \pm 0.01$ \\
\hline Amiloride & $0.16 \pm 0.01$ & $0.15 \pm 0.02$ & $0.14 \pm 0.01$ & $0.14 \pm 0.01$ \\
\hline CFL & $0.18 \pm 0.01$ & $0.20 \pm 0.01$ & $0.20 \pm 0.01$ & $0.18 \pm 0.02$ \\
\hline $\mathrm{CFL}+$ Amiloride & $0.19 \pm 0.02$ & $0.29 \pm 0.04^{*}$ & $0.34 \pm 0.05^{*}$ & $0.43 \pm 0.05^{*}$ \\
\hline
\end{tabular}

RPP: Renal perfusion pressure; RVR: renal vascular resistance; UF: urinary flow; GFR: glomerular filtration rate. CFL (10 $\mu \mathrm{g} / \mathrm{mL}$ ), amiloride $\left(10^{-4} \mathrm{M}\right)$ or CFL + amiloride. Mean \pm S.E.M. $(\mathrm{n}=5)$ and compared by Student test. * $\mathrm{p}<0.05$ compared to control $(\mathrm{Krebs}-$ Henseleit). 

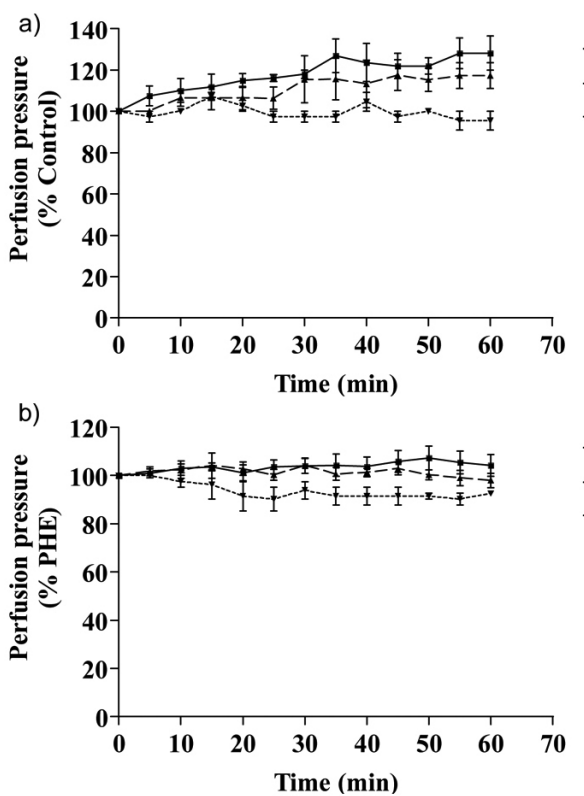

varied in efficacy and mechanisms either in vivo (paw edema) or in vitro (isolated aorta), and involved

the nitric oxide pathway (Assreuy et al., 2009). Thus, changes in renal hemodynamics and tubular physiology may be a consequence of the release of inflammatory mediators from kidney cells (Koeppen; Stanton, 1997). Moreover, the increased release of renin elicited by amiloride can interfer in its mild natriuretic and diuretic effects (Endemann et al. 2002). In fact, amiloride intensified the vascular effects (RPP and RVR) elicited by CFL.

$\rightarrow-$ CFL $3 \mu \mathrm{g} / \mathrm{mL} / \mathrm{min}$.

-.-- CFL $10 \mu \mathrm{g} / \mathrm{mL} / \mathrm{min}$.

FIGURE 1 - Effect of Cratylia floribunda lectin (CFL; 3 or $10 \mu \mathrm{g} / \mathrm{mL} / \mathrm{min}$ ) on mesenteric vascular bed. Panel (A) shows its effect in the basal mesenteric vascular tonus and (B) shows the effects of CFL in vascular bed contracted with phenylephrine (PHE; $5 \mu \mathrm{M}$ ). Mesenteric bed was perfused with Krebs Henseleit solution at $37{ }^{\circ} \mathrm{C}$. Data were expressed as mean \pm S.E.M. $(n=4)$ and compared by using Student $t$ test. ${ }^{*} \mathrm{p}<0.05$ compared to control (Krebs-Henseleit).

CFL did not alter the tubular transport of sodium or chloride, but reduced the tubular transport of potassium at $60 \mathrm{~min}\left(\%_{\mathrm{TK}^{+}}{ }^{+}=7.19\right), 90 \mathrm{~min}\left(\%_{\mathrm{TK}^{+}}{ }^{+}=20.79\right)$ and $120 \mathrm{~min}\left(\%_{\mathrm{TK}}{ }^{+}=22.53\right)$. As expected, amiloride reduced the transport of sodium at $60 \mathrm{~min}\left(\%_{\mathrm{TNa}}{ }^{+}=8.16\right), 90 \mathrm{~min}$ $\left(\%_{\mathrm{TNa}}{ }^{+}=10.14\right)$ and $120 \mathrm{~min}\left(\%_{\mathrm{TNa}}{ }^{+}=7.25\right)$, but not that of chloride or potassium, whereas its addition to the perfusion solution before CFL did not alter none of these ion transports (Table II). In respect to renal tubular transport, CFL decreased $\% \mathrm{TK}^{+}$, but did not alter $\% \mathrm{TNa}^{+}$or $\% \mathrm{TCl}^{-}$. Since amiloride, recognized as a potent potassium sparing drug, increases sodium levels in the distal segments, its effect opposes potassium reabsorption by CFL in this renal segment. The tubular alteration in

TABLE II - Effects of the lectin from Cratylia floribunda seeds on ions tubular transport

\begin{tabular}{lcccc}
\hline Ions transport & $30 \mathrm{~min}$ & $60 \mathrm{~min}$ & $90 \mathrm{~min}$ & $120 \mathrm{~min}$ \\
\hline \% $\mathbf{T N a}^{+}$ & & & & \\
Control & $80.86 \pm 0.16$ & $81.11 \pm 0.26$ & $80.66 \pm 0.31$ & $81.28 \pm 0.26$ \\
Amiloride & $79.66 \pm 1.68$ & $74.49 \pm 2.79^{*}$ & $72.48 \pm 2.72^{*}$ & $75.38 \pm 1.45^{*}$ \\
CFL & $79.42 \pm 1.04$ & $79.15 \pm 0.89$ & $78.58 \pm 1.28$ & $78.88 \pm 1.80$ \\
CFL + Amiloride & $80.06 \pm 1.11$ & $80.18 \pm 1.77$ & $81.59 \pm 1.60$ & $78.17 \pm 2.02$ \\
\% TK & & & & \\
Control & $69.13 \pm 0.52$ & $69.40 \pm 0.60$ & $71.84 \pm 1.18$ & $69.94 \pm 0.88$ \\
Amiloride & $69.57 \pm 1.67$ & $67.41 \pm 2.94$ & $65.20 \pm 3.12$ & $67.21 \pm 1.75$ \\
CFL & $70.52 \pm 1.87$ & $64.41 \pm 3.89 *$ & $56.90 \pm 5.49^{*}$ & $54.18 \pm 7.63 *$ \\
CFL + Amiloride & $71.94 \pm 1.52$ & $72.62 \pm 1.76$ & $73.37 \pm 1.55$ & $69.48 \pm 2.10$ \\
\%TCl & & & & \\
Control & $80.90 \pm 0.34$ & $82.25 \pm 1.08$ & $78.32 \pm 0.90$ & $79.53 \pm 0.81$ \\
Amiloride & $77.29 \pm 2.69$ & $73.03 \pm 5.25$ & $70.93 \pm 4.78$ & $72.26 \pm 2.52$ \\
CFL & $77.09 \pm 1.75$ & $76.17 \pm 2.18$ & $75.05 \pm 2.78$ & $75.78 \pm 3.34$ \\
CFL + Amiloride & $77.17 \pm 2.58$ & $75.41 \pm 4.93$ & $76.99 \pm 4.44$ & $73.00 \pm 4.18$ \\
\hline
\end{tabular}

$\% \mathrm{TNa}^{+}$: sodium tubular transport percentage; $\% \mathrm{TK}^{+}$: potassium tubular transport percentage; \% $\mathrm{TCl}^{-}$: chloride tubular transport percentage. CFL $(10 \mu \mathrm{g} / \mathrm{mL})$, amiloride $\left(10^{-4} \mathrm{M}\right)$ or CFL + amiloride. Mean \pm S.E.M. $(\mathrm{n}=5)$ and compared by Student test. $* \mathrm{p}<0.05$ compared to control (Krebs-Henseleit). 
$\% \mathrm{TK}^{+}$elicited by CFL could be a consequence of an indirect mechanism.

Renal effects elicited by different Diocleinae lectins are quite diverse. For instance, CFL and ConBr greatly increased RPP and RVR in the perfused rat kidney, but the increase caused by CFL was twice longer than that induced by $\mathrm{ConBr}$ (Teixeira et al., 2001. On the other hand, ConA and DguiL showed minor alterations in RPP and RVR (Havt et al., 2003). ConA increased these parameters at $60 \mathrm{~min}$, whereas DguiL increased from 90 to $120 \mathrm{~min}$. In addition, only ConBr, but not DguiL, ConA (Teixeira et al., 2001, Havt et al., 2003) or CFL increased UF and GFR. With respect to tubular ion transport, ConBr reduced all transports (potassium, sodium and chloride) (Teixeira et al., 2001), while ConA only potassium (Havt et al., 2003). However, DguiL did not influence any of these parameters (Havt et al., 2003). Remarkably, CFL decreased potassium but not sodium or chloride transport.

Diocleinae lectins display high homology in their primary structures and share biochemical and structural features such as the conserved amino acid residues present in the carbohydrate binding sites (Tyr12, Asn14, Leu99, Tyr100, Asp208 and Arg228), metal binding sites (Glu8, Asp10, Tyr12, Asn14, Asp19, His24, Val32, Ser34, Asp208 and Arg228) and in hydrophobic cavities (Tyr54, Leu81, Leu85, Va189, Va191, Phe111, Ser113, Val179, Ile181, Phe191, Phe212 and Ile214) (Cavada et al. 2001). Despite this structural homology, the observed antinociceptive and anti-inflamatory responses of Diocleinae lectins were quite different: the contortions induced by acetic acid in mice were inhibited by $55 \%$ by DguiL and by $46 \%$ by CFL (Holanda et al., 2009); in the formalin test, ConBr inhibited the neurogenic phase by $26 \%$ (De Freitas et al., 2013), while DguiL did not express such behaviour (Holanda et al., 2009). With respect to the anti-inflammatory activity, the rat peritonitis induced by carrageenan was inhibited by $63 \%$ by DguiL and by $62 \%$ by CFL (Assreuy et al., 1997; Alencar et al., 1999; Figueiredo et al., 2009); the rat paw-edema induced by carrageenan was reduced by $17 \%$ by DguiL and by $30 \%$ by CFL, but not by $\mathrm{ConBr}$ (Assreuy et al., 1997).

The presence of specific amino acids in the structure of Diocleinae lectins (Del Sol et al., 2007) may explain such differences in pharmacological activities. The substitution of the amino acids Gln155 and Glu155, present in all Diocleinae by His 155 solely on ConBr (Calvete et al., 1999) could also explain the better efficacy of $\mathrm{ConBr}$, either in its antinociceptive property as well as in its renal hemodynamic changes compared to other lectins. Furthermore, the different activities and potencies observed between CFL and ConBr could be explained by the presence of specific amino acids in CFL, which are not present in $\mathrm{ConBr}$ due to the evolutionary processes in ancestors (Del Sol et al., 2007).

The knowledge of structural aspects and phylogenetic proximity among Diocleinae lectins is essential for the understanding of its relation structure-activity. Besides, this study opens avenues for the use of CFL as an important pharmacological tool to elucidate mechanisms implied in cardiovascular disorders.

\section{CONCLUSION}

The seed lectin of Cratylia floribunda alters renal hemodynamic parameters showing a kaliuretic effect, that could be of tubular origin, rather than a result from haemodynamic alterations.

\section{ACKNOWLEDGEMENTS}

The following agencies are kindly acknowledged for their financial support: CNPq, CAPES, PADCT, FUNCAP and BNB.

\section{REFERENCES}

ALENCAR, N.M.N.; TEIXEIRA, E.H.; ASSREUY, A.M.S.; CAVADA, B.S.; FLORES, C.A.; RIBEIRO, R.A. Leguminous lectins as tools for studying the role of sugar residues in leukocyte recruitment. Mediators Inflamm., v.8, n.2, p.107-113, 1999.

ASSREUY, A.M.S.; SHIBUYA, M.D.; MARTINS, G.J.; DE SOUZA, M.L.; CAVADA, B.S.; MOREIRA, R.A.; OLIVEIRA, J.T.; RIBEIRO, R.A.; FLORES, C.A. Antiinflammatory effect of glucose-mannose binding lectins isolated from Brazilian beans. Mediators Inflamm., v.6, n.3, p.201-210, 1997.

ASSREUY, A.M.S.; FONTENELE, S.R.; PIRES, A.F.; FERNANDES, D.C.; RODRIGUES, N.V.; BEZERRA, E.H.; MOURA, T.R.; DO NASCIMENTO, K.S.; CAVADA, B.S. Vasodilator effects of Diocleinae lectins from the Canavalia genus. Naunyn-Schmiedebergs Arch. Pharmacol., v.380, n.6, p.509-521, 2009.

BANCHONGLIKITKUL, C.; SMART, J.D.; GIBBS, R.V.; COOK, D.J. Binding of some Diocleinae lectins to the mucosal surfaces of the eye and mouth. Br. J. Biomed. Sci., v. 57, n.1, p.7-12, 2000. 
BARRAL-NETTO, M.; SANTOS, S.B.; BARRAL, A.; MOREIRA, L.I.M.; SANTOS, C.F.; MOREIRA, R.A.; OLIVEIRA, J.T.A.; CAVADA, B.S. Human lymphocyte stimulation by legume lectins from the Dioclea tribe. Immunol. Invest., v.21, n.4, p.297-303, 1992.

BOWMAN, R.H. Gluconeogenesis in the isolated perfused isolated rat kidney. J. Biol. Chem., v.245, n.7, p.1604-1612, 1970 .

CALVETE, J.J.; THOLE, H.H.; RAIDA, M.; URBANKE, C.; ROMERO, A.; GRANGEIRO, T.B.; RAMOS, M.V.; ALMEIDA DA ROCHA, I.M.; GUIMARÃES, F.N.; CAVADA, B.S. Molecular characterization and crystallization of Diocleinae lectins. Biochim. Biophys. Acta, v.1430, n.2, p.367-375, 1999.

CAVADA, B.S.; BARBOSA, T.; ARRUDA, S.; GRANGEIRO, T.B.; BARRAL-NETO, M. Revisiting proteus: do minor changes in lectin structure matter in biological activity? Lessons from and potential biotechnological uses of the Diocleinae subtribe lectins. Curr. Protein Pept. Sci., v.2, n.2, p.123-135, 2001.

DAM, T.K.; CAVADA, B.S.; GRANGEIRO, T.B.; SANTOS, C.F.; DE SOUSA, F.A.; OSCARSON, S.; BREWER, C.F. Diocleinae lectins are a group of proteins with conserved binding sites for the core trimannoside of asparagine-linked oligosaccharides and differential specificities for complex carbohydrates. J. Biol. Chem., v.273, n.20, p.12082-12088, 1998.

DE FREITAS, A.P.; ASSREUY, A.M.S.; LOPES, E.A.; CELEDÔNIO, N.R.; SOARES, C.E.; RODRIGUES, N.V.; SOUSA, P.L.; BENEVIDES, R.G.; NAGANO, C.S.; CAVADA, B.S.; LEAL-CARDOSO, J.H.; COELHO-DESOUZA, A.N.; SANTOS, C.F. Opioid-like antinociceptive effects of oral administration of a lectin purified from the seeds of Canavalia brasiliensis. Fundam. Clin. Pharmacol., v.27, n.2, p.201-209, 2013.

DEL SOL, F.G.; CAVADA, B.S.; CALVETE, J.J. Crystal structures of Cratylia floribunda seed lectin at acidic and basic pHs. Insights into the structural basis of the $\mathrm{pH}-$ dependent dimer-tetramer transition. J. Struct. Biol., v.158, n.1, p.1-9, 2007.
ENDEMANN, D.; MARIENHAGEN, J.; STUBANUS, M.; LUGER, R.R.; FISCHEREDER, M.; RIEGGER, G.A.; KRAMER, K.B. Volume independent stimulation of renin secretion by a single dose of amiloride in man. Arzneimittelforschung, v.52, n.9, p.677-683, 2002.

FIGUEIREDO, J.G.; BITENCOURT, F.S.; MOTA, M.R.; SILVESTRE, P.P.; AGUIAR, C.N.; BENEVIDES, R.G.; NASCIMENTO, K.S.; DE MOURA, T.R.; DAL-SECCO, D.; ASSREUY, A.S.M.; CUNHA, F.Q.; VALE, M.R.; CAVADA, B.S.; ALENCAR, N.M. Pharmacological analysis of the neutrophil migration induced by $D$. rostrata lectin: involvement of cytokines and nitric oxide. Toxicon, v.54, n.6, p.736-744, 2009.

FONTELES, M.C.; COHEN, J.J.; BLACK, A.J.; WERTHEIM, S.J. Support of renal kidney function by long-chain fatty acids derived from renal tissue. Am. J. Physiol., v.244, n.3, p.235-246, 1983.

GOMES, J.C.; FERREIRA, R.R.; CAVADA, B.S.; MOREIRA, R.A.; OLIVEIRA, J.T.A. Histamine release induced by glucose (mannose)-specific lectins isolated from Brazilian beans. Comparison with Concanavalin A. Agents Actions, v.41, n.4-5, p.132-135, 1994.

HAVT, A.; BARBOSA, P.S.F.; SOUSA, T.M.; MARTINS, A.M.C.; NOBRE, A.C.L.; NASCIMENTO, K.S.; TEIXEIRA, E.H.; PINTO, V.P.T.; SAMPAIO, A.H.; FONTELES, M.C.; CAVADA, B.S.; MONTEIRO, H.S.A. Renal alterations promoted by the lectins from Canavalia ensiformis (ConA) and Dioclea guianensis (Dguil) seeds. Protein Pept. Lett., v.10, n.2, p.191-197, 2003.

HOLANDA, F.R.; COELHO-DE-SOUZA, N.A.; ASSREUY, A.M.S.; LEAL-CARDOSO, J.H.; PIRES, A.F.; NASCIMENTO, K.S.; CAVADA, B.S.; SANTOS, C.F. Antinociceptive activity of lectins from Diocleinae seeds on acetic acid-induced writhing test in mice. Protein Pept. Lett., v.16, n.9, p.1088-1092, 2009.

INGHAM, J.L. Systematic aspects of phytoalexin formation within tribe Phaseoleae of the Leguminosae (subfamily Papilionoideae). Biochem. Sys. Ecol., v.18, n.5, p.329-343, 1990.

KOEPPEN, B.M.; STANTON, B.A. Glomerular filtration and renal blood flow. In___ Renal Physiology. 2.ed. St Louis: Mosby, 1997. cap.3, p.31-51. 
MARTINEZ-MALDONATO, M.; OPAVA-STITZER, S. Free water clearance curves during saline, mannitol, glucose and urea. J. Physiol., v.280, p.487-497, 1978.

MCGREGOR, D.D. The effect of sympathetic nerve stimulation on vasoconstrictor responses in perfused mesenteric blood vessels of the rat. J. Physiol., v.177, n.1, p.21-30, 1965.

OLIVEIRA, J.T.A.; CAVADA, B.S.; MOREIRA, R.A. Isolation and partial characterization of a lectin from Cratylia floribunda Mart. Seeds. Rev. Bras. Bot., v.14, n.1, p.61-66, 1991.

TEIXEIRA, H.E.; HAVT, A.; BARBOSA, P.S.F.; MENEZES, D.B.; FONTELES, M.C.; MONTEIRO, H.S.A.; SAMPAIO, A.H.; CAVADA, B.S. Renal effects of the lectin from Canavalia brasiliensis seeds. Protein Pept. Lett., v.8, p.477-484, 2001.
YAMAZAKI, N.; KOJIMA, S.; BOVIN, N.V.; ANDRÉ, S.; GABIUS, S.; GABIUS, H-J. Endogenous lectins as targets for drug delivery. Adv. Drug Deliv. Rev., v.43, n.2-3, p.225$244,2000$.

WALSER, M.; DAVIDSON, D.G.; ORLOFF, J. The renal clearance of alkali-stable inulin. J. Clin. Invest., v.34, n.10, p.1520-1523, 1955.

Received for publication on $02^{\text {nd }}$ February 2014 Accepted for publication on $16^{\text {th }}$ August 2015 
